\title{
Effects of glucocorticoids on the skin
}

Wpływ glikokortykosteroidów na skórę

\author{
1 Department of Physiology, Wroclaw Medical University, Wrockaw, Poland \\ ${ }^{2}$ Department of Normal Anatomy, Wroclaw Medical University, Wrocław, Poland \\ ${ }^{3}$ Department of Dermatology, Venereology and Allergology, Wroclaw Medical University, Wrockaw, Poland \\ Correspondence: Anna Otlewska, Wiązowa 7/1, 53-127 Wrocław, Poland, tel.: +48500 074 744, e-mail: a.otlewska@gmail.com
}

Abstract Glucocorticoids are widely used in the treatment of many diseases. They have multiple therapeutic applications mainly because of their anti-inflammatory, immunosuppressive and antiproliferative activity. Glucocorticoids are broadly used in the therapy of dermatological diseases. Various routes of glucocorticoids administration are known. In the treatment of skin disorders, glucocorticoids are often administered topically. It must be noted that glucocorticoid-induced complications may occur not only as a result of systemic treatment, but also topical application of glucocorticoids to the skin. Commonly reported cutaneous adverse effects resulting from glucocorticoid therapy include changes in facial appearance - rounded appearance of the face, redness, development of stretch marks, difficulty in wound healing, and easy bruising. It needs to be highlighted that glucocorticoids also affect metabolism, water and electrolyte balance, and bones. Therefore, in addition to dermatological disorders, they may also cause many other types of complications. As a result, a degree of caution is advised in the use of drugs of this class. In order to reduce the risk of adverse effects, glucocorticoids should be used at the smallest effective dose for the shortest possible time.

Keywords: glucocorticoids, anti-inflammatory effect, steroid therapy, inflammatory mediators

Glikokortykosteroidy są lekami znajdującymi zastosowanie w leczeniu wielu chorób. Wykorzystuje się przede wszystkim ich działanie przeciwzapalne, immunosupresyjne i antyproliferacyjne. Są powszechnie stosowane w leczeniu chorób dermatologicznych. Znane są różne drogi podawania glikokortykosteroidów. W leczeniu chorób skóry często możliwe jest ich podawanie miejscowe. Należy zwrócić uwagę na to, że do wystąpienia powikłań może prowadzić nie tylko ogólnoustrojowe przyjmowanie tych leków, ale także aplikowanie ich na skórę. Do często opisywanych skórnych działań niepożądanych wynikających z glikokortykosteroidoterapii należą: zmiany w wyglądzie twarzy - zaokrąglenie jej kształtu, zaczerwienienie, rozwój rozstępów skórnych, trudności w gojeniu się ran oraz łatwe powstawanie wybroczyn. Trzeba pamiętać, że glikokortykosteroidy mają również wpływ na metabolizm, gospodarkę wodno-elektrolitową oraz na kości, w związku z czym mogą powodować wiele innych - poza dermatologicznymi - powikłań. Z tego względu terapię tymi lekami należy prowadzić z ostrożnością. Podstawowymi elementami leczenia, pozwalającymi zredukować ryzyko działań niepożądanych, są stosowanie najmniejszej skutecznej dawki leku oraz prowadzenie terapii przez jak najkrótszy czas.

Słowa kluczowe: glikokortykosteroidy, działanie przeciwzapalne, steroidoterapia, mediatory zapalne 


\section{INTRODUCTION}

$\mathrm{G}$ lucocorticoids (GCs) are steroid hormones produced predominantly in the adrenal cortex. Their secretion is regulated by the hypothalamic-pituitary-adrenal axis ${ }^{(1)}$.

Synthetic GCs were first introduced into clinical practice in the $1950 \mathrm{~s}^{(2)}$. Glucocorticoids are used in the treatment of many diseases, especially autoimmune disorders ${ }^{(3)}$, mainly based on their anti-inflammatory ${ }^{(4)}$, immunosuppressive and antiproliferative activity ${ }^{(5)}$.

The main routes of administration of GCs are: oral, intravenous, intranasal, topical, inhaled, and intra-articular ${ }^{(6)}$.

Prolonged exposure to excessive amounts of GCs leads to Cushing's syndrome. The disorder can be caused by the body's own overproduction of hormones (endogenous Cushing's syndrome) or exogenous GC ingestion (exogenous Cushing's syndrome $)^{(7)}$.

\section{THERAPEUTIC USE}

Glucocorticoids produce their effects via two pathways: genomic, where the onset of response occurs within hours or days; and nongenomic, where the onset of action is observed after seconds or minutes ${ }^{(3)}$. Glucocorticoids are hormones binding to receptors in the cytoplasm. After hormone binding, the receptors act as transcription factors. In this way, GCs produce either an increase or decrease in gene transcription ${ }^{(4,6)}$. The nongenomic effect of GCs may arise from hormone binding to receptors located on the cell membrane ${ }^{(8)}$, and the impact of GCs on lipids in the plasma membrane ${ }^{(9)}$. The effects of GCs depend on the dose used ${ }^{(8)}$.

Glucocorticoids, especially when administered topically, are used predominantly in the treatment of skin disorders. They are the primary agents in the therapy of eczema, lichen planus, and lichen simplex chronicus. Glucocorticoids are also used after insect bites and in the treatment of burns ${ }^{(10)}$. In addition, they have therapeutic applications as adjunctive agents in the treatment of psoriasis, chronic lupus erythematosus, and seborrhoeic dermatitis. In rare cases, they can be used to treat bullous pemphigoid and cutaneous mastocytosis $^{(11)}$. Also, GCs are effective in controlling hirsutism secondary to congenital adrenal hyperplasia ${ }^{(12)}$. Topical GCs help to relieve skin redness, swelling or itching. They can be applied to the skin and mucosa ${ }^{(11)}$.

In addition to their reported benefits in dermatology, GCs are widely used in the treatment of conditions in other medical disciplines including pulmonary disorders such as asthma ${ }^{(13)}$, or rheumatic disorders, especially systemic lupus erythematosus and rheumatoid arthritis ${ }^{(14)}$.

The anti-inflammatory effect of topical GCs in the treatment of dermatological diseases is due to their activity inhibiting the secretion of proinflammatory proteins by fibroblasts, keratinocytes and leukocytes in the skin ${ }^{(9)}$. In addition, GCs and monocytes, and reduce their ability to adhere to the vascular endothelium. Also, they cause a drop in the number of Langerhans cells and affect their antigen-presenting ability ${ }^{(15)}$. Glucocorticoids are also known to reduce endothelial permeability ${ }^{(16)}$. Other effects produced by drugs of this class include an increase in the apoptosis of $\mathrm{T}$ and mast cells, and inhibition of the processes of maturation and recruitment, and the lifetime of eosinophils ${ }^{(17)}$. In addition, GCs inhibit the proliferation of fibroblasts and keratinocytes $^{(14)}$, and suppress the activity of phospholipase A2, leading to a reduction in the synthesis of inflammatory mediators $^{(11)}$.

\section{ADVERSE REACTIONS}

Adverse effects accompanying GC treatment are associated with the widespread distribution of GC receptors in the body. Consequently, GC-based therapy produces an effect not only on target tissues, but also other organs, resulting in the development of adverse drug reactions ${ }^{(18)}$. In addition to anti-inflammatory, immunosuppressive and antiproliferative effects, GCs modulate carbohydrate, lipid and protein metabolism, affect bones, and play a role in regulating water and electrolyte balance ${ }^{(14,19,20)}$. The best-known potential adverse effects of GC treatment include the development of osteoporosis and the risk of fractures, arterial hypertension, cataract and glaucoma, mental disorders, and an increased risk of infections. Moreover, GC exposure can induce muscle atrophy, and lead to carbohydrate and lipid metabolism disorders, as well as an increase in body weight ${ }^{(6,21,22)}$ with central fat deposition and the development of abdominal obesity. Hypercortisolism may be accompanied by the so-called buffalo hump and filling of the supraclavicular fossae ${ }^{(23)}$. It is important to note that GCs inhibit the hypothalamic-pituitary-adrenal axis. Consequently, adrenal insufficiency may occur upon discontinuation of therapy ${ }^{(24)}$. Therefore, when treatment exceeds 3 weeks, GCs should be discontinued gradually ${ }^{(25)}$.

When discussing complications associated with steroid therapy, it needs to be added that topical GCs may also trigger systemic adverse effects. The risk of adverse drug reactions is particularly high in children and individuals with damaged skin barrier. In addition, the risk is further increased when GCs are applied to large skin areas, in highly vascularised regions, and under occlusion ${ }^{(26)}$. The risk of adverse effects is also linked to the chemical structure of GCs, and the excipient used in the formulation. The most potent absorption can be achieved with ointments ${ }^{(27)}$.

Hypercortisolism leads to a number of changes in appearance and skin complications. Characteristic signs include facial plethora (redness) and rounding (referred to as "moon face") resulting from the accumulation of fatty tissue $^{(28)}$.

Moreover, GCs may lead to the development of purple-red stretch marks on the skin, and impair wound healing ${ }^{(29)}$. 
Stretch marks associated with GC therapy are different in appearance from those accompanying a rapid change in body weight. They are wide and purple-red in colour ${ }^{(30)}$. Impaired wound healing may result from the impact exerted by GCs on keratinocyte growth factor (KGF). Under normal conditions, KGF is secreted after skin damage and induces the proliferation of keratinocytes ${ }^{(31)}$. Glucocorticoids may inhibit KGF production and thus interfere with wound healing. The effect is both dose- and time-dependent ${ }^{(32)}$.

Steroid therapy may cause easy bruising ${ }^{(33)}$, formation of petechiae ${ }^{(25)}$, and a decrease in the density of cutaneous blood vessels (mediated by the angiostatic effects of GCs) ${ }^{(34)}$. Topically administered GCs may trigger contact dermatitis as a delayed-type allergic reaction ${ }^{(2)}$.

Prolonged topical administration of GCs may result in steroid dermatitis resembling rosacea ${ }^{(35)}$. Steroid dermatitis presents as papulovesicular skin eruptions with coexisting erythematous lesions ${ }^{(36)}$.

Another potential complication of GCs is the development of atrophic changes including telangiectasias, erosions and ulcers, as well as so-called stellate pseudoscars $^{(37)}$. Skin atrophy is characterised by thinning of the skin and an increase in transparency and susceptibility to injuries ${ }^{(38)}$. With the topical application of GCs, the areas most exposed to the risk of skin atrophy are the face, neck and cubital fossae. Skin atrophy may result from hormone-induced disorders of collagen, elastin and glycosaminoglycan synthesis ${ }^{(39)}$, as well as increased protein catabolism ${ }^{(30)}$. It affects both the epidermis and the dermis. It is also worth highlighting that GCs suppress the synthesis of hyaluronate, the main glycosaminoglycan known to play an important role in the proliferation, migration, cell differentiation, angiogenesis, and repair processes ${ }^{(40)}$. Importantly, some of the effects of GCs may be desirable in the treatment of certain diseases but, at the same time, induce adverse reactions in other pathological conditions. For example, on the one hand, the antiproliferative effect of GCs brings benefits in the treatment of psoriasis. On the other hand, though, it can induce complications including skin atrophy ${ }^{(10)}$.

Steroid therapy also adversely affects the skin's immune response and weakens its protective barrier function ${ }^{(41)}$, potentially leading to the development of skin infections ${ }^{(33)}$. Topically applied GCs may cause folliculitis, skin hyper- or hypopigmentation, and perioral dermatitis ${ }^{(39)}$. Perioral dermatitis presents with small papular, pustular and macular lesions located around the mouth. A point of note is that the condition may also develop after inhaled and intranasal administration of $\mathrm{GCs}^{(42)}$.

Another complication seen with both topical and systemic steroid therapy is hypertrichosis, i.e. abnormal amount of hair growth over the body. Hypertrichosis should be differentiated from hirsutism, in which excessive hair growth is limited to androgen-dependent areas, and which occurs in women ${ }^{(43)}$.
Also, a relationship between steroid therapy and the development of skin malignancies has been found. In their study, Jensen et al. found that GC treatment correlated with the prevalence of basal and squamous cell carcinoma, nonHodgkin's lymphoma, and melanoma. The incidence of squamous cell carcinoma and lymphoma exhibited a positive correlation with the dose of GCs, and basal cell carcinoma - with the duration of steroid therapy. Neither the dose used nor the duration of steroid therapy has been shown to contribute to the risk of malignant melanoma ${ }^{(44)}$.

\section{PREVENTION OF ADVERSE EFFECTS}

Because of their potential adverse effects, GCs must be used with caution. Nevertheless, adverse effects can be partially prevented. Above all, however, GCs should be used only if indications exist for the use of steroid therapy. This is because complications related to GC treatment often arise in patients taking the drugs without any dermatological supervision, as some GCs are available on an OTC basis, without a doctor's prescription ${ }^{(45)}$. Furthermore, preference should always be given to GCs with a short and medium duration of action, such as prednisone, prednisolone or hydrocortisone. If possible, topical formulations should be used as the first choice. In order to minimise the risk of adverse effects, GCs should be used in combination with other drugs known to produce a synergistic response. With this approach, it is possible to reduce the dose of GCs or the period of treatment ${ }^{(46)}$.

The risk of adverse drug reactions increases with the dose and duration of therapy. It must be remembered that even small doses of GCs can lead to the development of complications. Prednisone at a daily dose of up to $5 \mathrm{mg}$ used for at least 6 months is associated with a $4.3 \%$ risk of developing cushingoid features, while daily doses exceeding $7.5 \mathrm{mg}$ increase the level of risk to $24.6 \%$. Consequently, GCs should be used at the lowest effective dose and for the shortest duration possible ${ }^{(25)}$.

\section{CONCLUSIONS}

Glucocorticoids exhibit a very broad spectrum of activity, which makes them useful in the treatment of many diseases. However, a major limitation in GC use is their potential to induce multiple adverse effects. During GC treatment, patients should be monitored for possible complications, and if any adverse effects occur, appropriate management should be initiated. Also, the recognised principles of therapy with GCs should be followed, so that the risk of adverse effects can be, at least partially, eliminated.

\section{Conflict of interest}

The authors do not declare any financial or personal links with other persons or organisations that might adversely affect the content of the publication or claim any right to the publication. 


\section{References}

1. Bereshchenko O, Bruscoli S, Riccardi C: Glucocorticoids, sex hormones, and immunity. Front Immunol 2018; 9: 1332.

2. Erdmann SM, Abuzahra F, Merk HF et al.: Anaphylaxis induced by glucocorticoids. J Am Board Fam Pract 2005; 18: 143-146.

3. Gensler LS: Glucocorticoids: complications to anticipate and prevent. Neurohospitalist 2013; 3: 92-97.

4. Lin KT, Wang LH: New dimension of glucocorticoids in cancer treatment. Steroids 2016; 111: 84-88.

5. Foti C, Calogiuri G, Cassano $\mathrm{N}$ et al.: Contact allergy to topical corticosteroids: update and review on cross-sensitization. Recent Pat Inflamm Allergy Drug Discov 2009; 3: 33-39.

6. Stojan G, Petri M: The risk benefit ratio of glucocorticoids in SLE: have things changed over the past 40 years? Curr Treatm Opt Rheumatol 2017; 3: 164-172.

7. Yorke E, Atiase Y, Akpalu J et al.: Screening for Cushing syndrome at the primary care level: what every general practitioner must know. Int J Endocrinol 2017; 2017: 1547358.

8. Alangari AA: Genomic and non-genomic actions of glucocorticoids in asthma. Ann Thorac Med 2010; 5: 133-139.

9. Schäfer-Korting $\mathrm{M}$, Kleuser B, Ahmed $\mathrm{M}$ et al.: Glucocorticoids for human skin: new aspects of the mechanism of action. Skin Pharmacol Physiol 2005; 18: 103-114.

10. Ahluwalia A: Topical glucocorticoids and the skin-mechanisms of action: an update. Mediators Inflamm 1998; 7: 183-193.

11. Sudhapriyadharshini G: Topical glucocorticoids - a review. J Pharm Sci Res 2014; 6: 244-246.

12. Loriaux DL: An approach to the patient with hirsutism. J Clin Endocrinol Metab 2012; 97: 2957-2968.

13. Barnes PJ: Glucocorticosteroids: current and future directions. Br J Pharmacol 2011; 163: 29-43.

14. Stojadinovic $O$, Lee $B$, Vouthounis $C$ et al.: Novel genomic effects of glucocorticoids in epidermal keratinocytes: inhibition of apoptosis, interferon-gamma pathway, and wound healing along with promotion of terminal differentiation. J Biol Chem 2007; 282: 4032-4034.

15. Kwatra G, Mukhopadhyay S: Topical corticosteroids: pharmacology. In: Lahiri K (ed.): A Treatise on Topical Corticosteroids in Dermatology. Use, Misuse and Abuse. Springer Singapore, Singapore 2018: 11-22.

16. Simon D, Borradori L, Simon HU: Glucocorticoids in autoimmune bullous diseases: are neutrophils the key cellular target? J Invest Dermatol 2013; 133: 2314-2315.

17. Taheri A, Cantrell J, Feldman SR: Tachyphylaxis to topical glucocorticoids; what is the evidence? Dermatol Online J 2013; 19: 18954.

18. Chow CC, Simons SS Jr: An approach to greater specificity for glucocorticoids. Front Endocrinol (Lausanne) 2018; 9: 76.

19. Dunford EC, Riddell MC: The metabolic implications of glucocorticoids in a high-fat diet setting and the counter-effects of exercise. Metabolites 2016; 6: 44.

20. Tiruneh F, Awan A, Didana A et al.: Preventing Cushing: iatrogenic Cushing syndrome due to ritonavir-fluticasone interaction. Cureus 2017; 9: e1484.

21. Bénard-Laribière A, Pariente A, Pambrun E et al.: Prevalence and prescription patterns of oral glucocorticoids in adults: a retrospective cross-sectional and cohort analysis in France. BMJ Open 2017; 7: e015905.

22. Patt $\mathrm{H}$, Bandgar T, Lila A et al.: Management issues with exogenous steroid therapy. Indian J Endocrinol Metab 2013; 17 (Suppl 3): S612-S617.

23. Guaraldi F, Salvatori R: Cushing syndrome: maybe not so uncommon of an endocrine disease. J Am Board Fam Med 2012; 25: 199-208.

24. Hopkins RL, Leinung MC: Exogenous Cushing's syndrome and glucocorticoid withdrawal. Endocrinol Metab Clin North Am 2005; 34: 371-384.
25. Nowak KM, Papierska L: Prevention and monitoring of the side effects of chronic corticosteroid therapy. Post Nauk Med 2014; 27: 852-859.

26. Nieman LK: Consequences of systemic absorption of topical glucocorticoids. J Am Acad Dermatol 2011; 65: 250-252.

27. Jeziorkowska R, Sysa-Jędrzejowska A, Samochocki Z: Topical steroid therapy in atopic dermatitis in theory and practice. Postepy Dermatol Alergol 2015; 32: 162-166.

28. Karczewska-Kupczewska M, Myśliwiec J, Górska M: Aktualne poglądy na diagnostykę zespołu Cushinga. Endokrynol Pol 2006; 57: 546-559.

29. Phillips PJ, Weightman W: Skin and Cushing syndrome. Aust Fam Physician 2007; 36: 545-547.

30. Jonczyk P: Symptomatologia zespołu Cushinga. Endokrynol Ped 2014; 13: 41-54.

31. Pikuła M, Langa P, Kosikowska P et al.: Komórki macierzyste i czynniki wzrostu w gojeniu ran. Postepy Hig Med Dosw 2015; 69: 874-885.

32. Chedid M, Hoyle JR, Csaky KG et al.: Glucocorticoids inhibit keratinocyte growth factor production in primary dermal fibroblasts. Endocrinology 1996; 137: 2232-2237.

33. Zhang YP, Gong Y, Zeng QY et al.: A long-term, observational cohort study on the safety of low-dose glucocorticoids in ankylosing spondylitis: adverse events and effects on bone mineral density, blood lipid and glucose levels and body mass index. BMJ Open 2015; 5: e006957.

34. El Zaoui I, Behar-Cohen F, Torriglia A: Glucocorticoids exert direct toxicity on microvasculature: analysis of cell death mechanisms. Toxicol Sci 2015; 143: 441-453.

35. Nikolakis G, Zouboulis CC: Skin and glucocorticoids: effects of local skin glucocorticoid impairment on skin homeostasis. Exp Dermatol 2014; 23: 807-808.

36. Shibata M, Katsuyama M, Onodera T et al.: Glucocorticoids enhance Toll-like receptor 2 expression in human keratinocytes stimulated with Propionibacterium acnes or proinflammatory cytokines. J Invest Dermatol 2009; 129: 375-382.

37. Jaworek A, Jaworek M, Szafraniec K et al.: Problem „sterydofobii” wśród pacjentów chorujących na atopowe zapalenie skóry przegląd zagadnień. Alerg Astma Immun 2018; 23: 143-149.

38. Johnson E, Groben P, Eanes A et al.: Vulvar skin atrophy induced by topical glucocorticoids. J Midwifery Womens Health 2012; 57 : 296-299.

39. Kaszuba A, Pastuszka M, Kaszuba A: Miejscowe glikokortykosteroidy w leczeniu chorób skóry - zalecane standardy postępowania. Forum Med Rodz 2009; 3: 347-358.

40. Gebhardt C, Averbeck M, Diedenhofen N et al.: Dermal hyaluronan is rapidly reduced by topical treatment with glucocorticoids. J Invest Dermatol 2010; 130: 141-149.

41. Slominski AT, Zmijewski MA: Glucocorticoids inhibit wound healing: novel mechanism of action. J Invest Dermatol 2017; 137: 1012-1014.

42. Tolaymat L, Hall MR: Dermatitis, perioral. [Updated 2020 May 3]. In: StatPearls [Internet]. StatPearls Publishing, Treasure Island (FL) 2020. Available from: https://www.ncbi.nlm.nih.gov/books/ NBK525968/.

43. Saleh D, Yarrarapu SNS, Cook C: Hypertrichosis. [Updated 2020 Jul 3]. In: StatPearls [Internet]. StatPearls Publishing, Treasure Island (FL) 2020. Available from: https://www.ncbi.nlm.nih.gov/ books/NBK534854/.

44. Jensen AØ, Thomsen HF, Engebjerg MC et al.: Use of oral glucocorticoids and risk of skin cancer and non-Hodgkin's lymphoma: a population-based case-control study. Br J Cancer 2009; 100: 200-205.

45. Sharma R, Abrol S, Wani M: Misuse of topical corticosteroids on facial skin. A study of 200 patients. J Dermatol Case Rep 2017; 11: 5-8.

46. Longui CA: Glucocorticoid therapy: minimizing side effects. J Pediatr (Rio J) 2007; 83 (5 Suppl): S163-S177. 